\title{
Silicon Promotes Adventitious Shoot Regeneration and Enhances Salinity Tolerance of Ajuga multiflora Bunge by Altering Activity of Antioxidant Enzyme
}

\author{
Iyyakkannu Sivanesan $^{1}$ and Byoung Ryong Jeong ${ }^{1,2,3}$ \\ ${ }^{1}$ Institute of Agriculture and Life Science, Gyeongsang National University, Jinju 660-701, Republic of Korea \\ ${ }^{2}$ Research Institute of Life Science, Gyeongsang National University, Jinju 660-701, Republic of Korea \\ ${ }^{3}$ Department of Horticulture, Division of Applied Life Science (BK21 Plus), Graduate School, \\ Gyeongsang National University, Jinju 660-701, Republic of Korea \\ Correspondence should be addressed to Byoung Ryong Jeong; brjeong@gnu.ac.kr
}

Received 23 October 2013; Accepted 10 December 2013; Published 9 January 2014

Academic Editors: A. A. Guevara-Garcia, E. T. Johnson, J. Sáenz-de-Cabezón Irigaray, and D. Ustek

\begin{abstract}
Copyright (C) 2014 I. Sivanesan and B. R. Jeong. This is an open access article distributed under the Creative Commons Attribution License, which permits unrestricted use, distribution, and reproduction in any medium, provided the original work is properly cited.

We investigated the effect of Si concentration on shoot regeneration and salinity tolerance of Ajuga multiflora. Addition of Si to the shoot induction medium significantly increased the frequency of shoot induction. The average number of shoots regenerated per explant decreased on the medium containing $\mathrm{NaCl}$ alone, while there was less decrease when the shoot induction medium was supplemented with both $\mathrm{NaCl}$ and $\mathrm{Si}$. The shoot induction percentage increased linearly with increasing concentration of $\mathrm{Si}$ in the $\mathrm{NaCl}$ containing medium. Addition of $\mathrm{Si}$ to the shoot induction medium significantly increased SOD, POD, APX, and CAT activity in regenerated shoot buds as compared with the control. The inclusion of $\mathrm{Si}$ to the $\mathrm{NaCl}$ containing medium significantly increased the SOD activity in leaves and roots, while it decreased POD, APX, and CAT activity in both organs. Scanning electron microscopic analysis showed that there are no distinct differences in the structure of stomata between the control and Si-treated plants. However, $\mathrm{NaCl}$ treatment significantly affected the structure and number of stomata as compared to the control. Wavelength dispersive X-ray analysis confirmed the high Si deposition in trichomes of plants grown in the Si containing medium but not in plants grown in the medium without Si.
\end{abstract}

\section{Introduction}

Silicon ( $\mathrm{Si}$ ) is most abundant mineral element both on the surface of the earth's crust and in the soil. In soil solutions, $\mathrm{Si}$ is found mainly as silicic acid which is taken up by plant roots. Though $\mathrm{Si}$ is present in most of the soil grown plants, but it is not considered to be an essential element for plant growth and development [1]. However, Si deficiency symptoms were observed in cucumber, sugarcane, and tomato [2]. Recent studies show the beneficial effects of $\mathrm{Si}$ on growth, development, and yield of plants [3-5]. Further, Si plays an important role in enhancing the resistance of plants to abiotic and biotic stresses such as drought, frost, metal toxicity, nutrient imbalance, salinity, and diseases [6]. The ameliorative effect of Si on plants suffering from abiotic stresses often occurs through counteracting oxidative stress by modulating antioxidant enzymes [7].

In vitro culture technique is often used for mass propagation of economically important plant species. In vitro morphogenetic response of plant species mainly depends on the addition of plant growth regulators to the culture medium [8]. Similarly, antioxidant enzyme activity has also marked effect on the growth and morphogenesis [9]. However, several physiological problems associated with the micropropagation such as browning, hyperhydricity, and shoot-tip necrosis are often encountered during the different stages of micropropagation [10]. These problems are mainly associated with culture environmental and nutritional factors. Further, in vitro regenerated plantlets often exhibit low survival rate due to transplantation shock caused by abiotic and biotic stresses. 
The application of Si has been shown to be beneficial for several plants particularly when those plants are exposed to abiotic and biotic stresses [6,7]. Addition of Si to the culture medium reduced hyperhydricity in Cotoneaster wilsonii [11] and Ornithogalum dubium [12]. The addition of Si to the culture medium has been proven to be advantageous for callus induction and plant regeneration in rice [13]. Recently, Máthé et al. [14] reported that Si has a significant effect on somatic embryo development, plant, and root morphogenesis in reed. The Si treatment reduced incidence of hyperhydricity by decreasing the accumulation of hydrogen peroxide and malondialdehyde and lowering the activity of enzymes ascorbate oxidase and glutathione reductase $[11,12]$. However, the mode of action of $\mathrm{Si}$ on shoot regeneration is not reported.

Soil salinity is one of the major abiotic stresses limiting growth and development of most plant species. In floricultural crops salinity affects growth, plant, and flower marketable quality, including visual injury, flower distortion, and reduced stem length [15]. Little information is available on salt tolerance of floricultural crops [16]. Thus, it is important to determine salt tolerance of bedding plants to minimize potential salt injuries. The determination of optimal Si concentration for salt tolerance of plants under in vivo conditions poses difficulties because of the complex interactions existing between the plant and different soil components [17]. Further, $\mathrm{Si}$ is a ubiquitous contaminant. In vitro culture is an ideal system for screening of salinity tolerance competence in plants as it can be carried out under controlled conditions with known amount of Si and other nutrients.

The genus Ajuga, belonging to the mint family (Lamiaceae), comprises about 301 species and occurs in the cooler parts of Europe, Asia, Africa, and Australia. The Ajuga species grow to $5-50 \mathrm{~cm}$ tall, with opposite leaves, which are attractive. The flowers are two-lipped and tubular and mostly blue, purple, or yellow in color. Many Ajuga species are used in horticulture as groundcover or border and in rock gardens but some are regarded as weeds [18]. Ajuga multiflora Bunge is a perennial herb $8-13 \mathrm{~cm}$ tall, widely distributed in Korea, north-eastern part of China, and Russia. It is cultivated as an ornamental groundcover in Korea and also used in a traditional medicine for the treatment of fever. It is reported to contain several phytoecdysteroids [19]. The plant is typically propagated by division of rhizomes. In order to provide enough plant material for commercial exploitation, the propagation of the plant using rhizome is not sufficient. In vitro propagation technique is being used widely for large-scale production of many plant species. So far, only few reports are available on in vitro propagation of Ajuga species [20-22]. The objective of this study was to determine the effect of $\mathrm{Si}$ on shoot regeneration and salt tolerance of $A$. multiflora.

\section{Materials and Methods}

2.1. Plant Materials and Surface Sterilization. Leaves with petioles were excised from greenhouse-grown plants, washed initially under running tap water for $30 \mathrm{~min}$, and then washed thoroughly in distilled water. The explants were surfacesterilized in $70 \%(\mathrm{v} / \mathrm{v})$ ethanol for $60 \mathrm{sec}, 1.5 \%(\mathrm{v} / \mathrm{v})$ sodium hypochlorite for $15 \mathrm{~min}$, and $0.1 \%(\mathrm{w} / \mathrm{v}) \mathrm{HgCl}_{2}$ for $5 \mathrm{~min}$. Each treatment was followed by 5 washes with sterile distilled water [22].

\subsection{Effect of $N^{6}-(2-i s o P e n t e n y l) a d e n i n e ~(2 i P)$ and Indole-3-} Acetic Acid (IAA) on Adventitious Shoot Regeneration. Leaf and petiole explants $(0.5-1.0 \mathrm{~cm})$ were prepared and inoculated on Murashige and Skoog (MS) medium containing $4.4,8.8$, or $12.2 \mu \mathrm{M} 2 \mathrm{iP}$ along with $5.7 \mu \mathrm{M}$ IAA for shoot bud induction. The medium consisted of MS salts and vitamins [23] supplemented with 3\% (w/v) sucrose and solidified with $0.8 \%(\mathrm{w} / \mathrm{v})$ agar. The $\mathrm{pH}$ of the medium was adjusted to 5.8 before autoclaving. The cultures were maintained at $25 \pm 1^{\circ} \mathrm{C}$ under a $16 \mathrm{~h}$ photoperiod with $45 \mu \mathrm{mol} \mathrm{m}^{-2} \mathrm{~s}^{-1}$ photosynthetic photon flux density (PPFD). The number of explants initiating shoot buds and the average number of shoot buds per explant were recorded after 35 days.

2.3. Effect of Si and $\mathrm{NaCl}$ on Adventitious Shoot Regeneration, Shoot Growth, and Rooting. Leaf and petiole explants were cultured on shoot induction (MS $+12.2 \mu \mathrm{M} 2 \mathrm{iP}+5.7 \mu \mathrm{M}$ IAA) medium containing $0,1.8,3.6$, or $7.2 \mathrm{mM} \mathrm{Si}$ alone or in combination with $50 \mathrm{mM} \mathrm{NaCl}$. Regenerated shoots were excised from explants and transferred to the respective medium without plant growth regulators and cultured for five weeks to induce the growth of shoots and roots.

2.4. Estimation of Antioxidant Enzymes. Regenerated shoot buds, leaf, and root tissue $(0.1 \mathrm{~g})$ were homogenized in $50 \mathrm{mM}$ phosphate buffer ( $\mathrm{pH} 7.0$ ) containing 1.0 mM EDTA, $0.05 \%$ Triton $\mathrm{X}-100,1.0 \mathrm{mM}$ polyvinylpyrrolidone (PVP), and $1.0 \mathrm{mM}$ ascorbate. The homogenate was centrifuged at $13,000 \mathrm{rpm}$ at $4^{\circ} \mathrm{C}$. The supernatant was used to estimate the activities of antioxidant enzymes. Protein content was estimated by the method of Lowry et al. [24]. Superoxide dismutase (SOD) activity was assayed by measuring its ability to inhibit the photochemical reduction of nitroblue tetrazolium (NBT) according to the method of Beauchamp and Fridovich [25]. Peroxidase (POD) activity was measured by following the procedure of Sadasivam and Manickam [26]. Ascorbate peroxidase (APX) activity was estimated according to the protocol described by Chen and Asada [27]. Catalase (CAT) activity was determined based on the method by Aebi [28].

2.5. Scanning Electron Microscopy (SEM) and Wavelength Dispersive X-Ray Analysis (WDXA). Leaves were separated from the $\mathrm{Si}$ and $\mathrm{NaCl}$ treatments. Leaf samples were cut into about $0.5 \mathrm{~mm}^{2}$ size and fixed in $3.0 \%(\mathrm{v} / \mathrm{v})$ glutaraldehyde ( $\left.\mathrm{pH} 7.5\right)$ overnight. Samples were washed three times with $0.1 \mathrm{M}$ PBS buffer $\left(137 \mathrm{mM} \mathrm{NaCl}+2.7 \mathrm{mM} \mathrm{KCl}+43 \mathrm{mM} \mathrm{Na}_{2} \mathrm{HPO}_{4}+\right.$ $\left.1.4 \mathrm{mM} \mathrm{KH} \mathrm{PO}_{4}\right)$ and then fixed in $1.0 \%$ (w/v) osmium tetroxide ( $\mathrm{pH} \mathrm{7.2)}$ for $2 \mathrm{~h}$ at $4^{\circ} \mathrm{C}$. The samples were washed four times with a PBS buffer, dehydrated through an ethanol series, and dried with a critical point dryer (CPD2, Pelco, CA, USA). Dried samples were positioned on aluminum stubs 
TABLE 1: Effect of 2-iP and NAA on adventitious shoot regeneration from leaf and petiole explants of $A$. multiflora.

\begin{tabular}{lccccc}
\hline \multicolumn{2}{c}{ Conc. $(\mu \mathrm{M})$} & \multicolumn{2}{c}{ Shoot induction $(\%)$} & \multicolumn{2}{c}{ No. of shoots/explant } \\
2 -iP & IAA & Leaf & Petiole & Leaf & Petiole \\
\hline 0 & 0 & $0.0^{\mathrm{d}}$ & $0.0^{\mathrm{d}}$ & $0.0^{\mathrm{d}}$ & $0.0^{\mathrm{d}}$ \\
4.4 & 5.7 & $41.2^{\mathrm{c}}$ & $37.8^{\mathrm{c}}$ & $2.6^{\mathrm{c}}$ & $2.0^{\mathrm{c}}$ \\
8.8 & 5.7 & $50.6^{\mathrm{b}}$ & $63.4^{\mathrm{b}}$ & $4.8^{\mathrm{b}}$ & $3.4^{\mathrm{b}}$ \\
12.2 & 5.7 & $73.3^{\mathrm{a}}$ & $76.6^{\mathrm{a}}$ & $8.5^{\mathrm{a}}$ & $6.2^{\mathrm{a}}$ \\
\hline
\end{tabular}

Means within a column followed by the same letters are not significantly different $(P \leq 0.05)$.

with double stick tape prior to gold coating in a sputter coater (SC7640, Polaron, Sussex, UK). The deposition of Si, $\mathrm{K}$, and $\mathrm{Na}$ in leaf samples was analyzed by a point analysis with wavelength dispersive spectrometer (JXA-8100, Jeol, Tokyo, Japan) combined with a SEM (LEO-435VP, Zesis, Jena, Germany) at $15 \mathrm{kV}$.

2.6. Statistical Analysis. The experiments were repeated thrice and 30 explants or shoot buds were used per treatment. Data were subjected to analysis of variance (ANOVA) by using SAS program (Release 9.1, SAS Institute, NC, USA), and Duncan's multiple range test was used to assess significant differences between mean values.

\section{Results and Discussion}

3.1. Effect of $2 i P$ and IAA on Adventitious Shoot Regeneration. Several ornamental plants are at present propagated in vitro by direct adventitious shoot regeneration. The surface sterilization method yielded $98 \%$ aseptic explants. Cytokinins are very effective in promoting adventitious shoot formation. However, both leaf and petiole explants did not respond well when $2 \mathrm{iP}$ alone was used [22]. In many plants, combination of auxin and cytokinin produced more shoots than cytokinin alone $[8,11]$. Thus, in this study we investigated the effect of combination of $2 \mathrm{iP}$ and IAA on adventitious shoot regeneration from leaf and petiole explants of $A$. multiflora. The explants cultured on plant growth regulators free MS medium did not develop shoot buds. When the MS medium was supplemented with $2 \mathrm{iP}$ and IAA both leaf and petiole explants developed shoot buds. Adventitious shoot buds were induced from the cut ends of both explants within 14 days of culture. An increase in the concentration of $2 \mathrm{iP}$ with constant IAA increased the percentage of shoot induction and number of shoots in both explants (Table 1 and Figures 1(a) and 2(a)). The greatest percentage of shoot induction with average number of shoots per explants was obtained on MS medium containing $12.2 \mu \mathrm{M} 2 \mathrm{iP}$ and $5.7 \mu \mathrm{M}$ IAA. Similar result was also observed in Rhododendron keiskei var. hypoglaucum [11].

3.2. Effect of Si and $\mathrm{NaCl}$ on Adventitious Shoot Regeneration, Shoot Growth, and Rooting. Addition of $\mathrm{Si}$ to the shoot induction medium significantly increased both the frequency of shoot induction and average number of shoots per explant. $\mathrm{Si}$ has been proven to be effective for shoot regeneration
TABLE 2: Effect of $\mathrm{Si}$ and $\mathrm{NaCl}$ on adventitious shoot regeneration from leaf and petiole explants of $A$. multiflora.

\begin{tabular}{lccccc}
\hline \multicolumn{2}{c}{ Conc. (mM) } & \multicolumn{2}{c}{ Shoot induction (\%) } & \multicolumn{2}{c}{ No. of shoots/explant } \\
Si & NaCl & Leaf & Petiole & Leaf & Petiole \\
\hline 0 & 0 & $73.3^{\mathrm{c}}$ & $76.6^{\mathrm{d}}$ & $8.5^{\mathrm{d}}$ & $6.2^{\mathrm{d}}$ \\
1.8 & 0 & $96.7^{\mathrm{b}}$ & $94.6^{\mathrm{b}}$ & $9.5^{\mathrm{cd}}$ & $9.2^{\mathrm{bc}}$ \\
3.6 & 0 & $100^{\mathrm{a}}$ & $100^{\mathrm{a}}$ & $13.8^{\mathrm{b}}$ & $10.8^{\mathrm{b}}$ \\
7.2 & 0 & $100^{\mathrm{a}}$ & $100^{\mathrm{a}}$ & $22.7^{\mathrm{a}}$ & $18.4^{\mathrm{a}}$ \\
0 & 50 & $43.6^{\mathrm{d}}$ & $31.2^{\mathrm{e}}$ & $3.0^{\mathrm{e}}$ & $1.7^{\mathrm{e}}$ \\
1.8 & 50 & $72.4^{\mathrm{c}}$ & $91.3^{\mathrm{c}}$ & $7.0^{\mathrm{d}}$ & $6.4^{\mathrm{d}}$ \\
3.6 & 50 & $97.2^{\mathrm{b}}$ & $98.6^{\mathrm{ab}}$ & $8.3^{\mathrm{d}}$ & $8.7^{\mathrm{c}}$ \\
7.2 & 50 & $100^{\mathrm{a}}$ & $100^{\mathrm{a}}$ & $10.7^{\mathrm{c}}$ & $7.4^{\mathrm{cd}}$ \\
\hline
\end{tabular}

Means within a column followed by the same letters are not significantly different $(P \leq 0.05)$.

in reed [14] and rice [13]. Increasing concentration of $\mathrm{Si}$ in the shoot induction medium significantly increased the average number of shoots per explant. Among the various concentrations tested, $7.2 \mathrm{mM}$ Si was found to be the best for adventitious shoot induction in both explants. When the explants were cultured on the shoot induction medium supplemented with 0-7.2 mM Si, the average number of shoot buds produced per explant ranged 8.5-22.7 in leaf (Table 2 and Figures $1(\mathrm{a})-1(\mathrm{~d})$ ) and $6.2-18.4$ in petiole (Table 2 and Figures 2(a)-2(d)). Adventitious shoot formation was obtained with a frequency of $73.3-100 \%$ in leaf and $76.6-$ $100 \%$ in petiole explants of $A$. multiflora cultured on the shoot induction medium supplemented with 0-7.2 mM Si. Among the two explants tested, leaf explant developed the greatest number of shoots than petiole explant. The highest frequency of shoot induction (100\%) with the average number of 22.7 shoots per leaf explant and 18.4 shoots per petiole explant was obtained on the shoot induction medium supplemented with $7.2 \mathrm{mM}$ Si. Gibberellins (GA) are plant growth regulators that play a pivotal role in the growth and development of plants. Si treatment increased $\mathrm{GA}_{1}$ and $\mathrm{GA}_{20}$ levels in rice cultivars [29]. The stimulating effect of $\mathrm{GA}_{3}$ on shoot induction has been reported in apple [30], Cephaelis ipecacuanha [31], and citrus [32]. Thus, the positive effect of $\mathrm{Si}$ on shoot induction may be due to altered endogenous level of GA (Table 2).

A preliminary experiment was conducted to test the effect of various concentrations of $\mathrm{NaCl}(0,25,50$, or $100 \mathrm{mM}$ ) on shoot regeneration of leaf and petiole explants of $A$. multiflora. Shoot regeneration was completely inhibited at $100 \mathrm{mM} \mathrm{NaCl}$. Addition of $50 \mathrm{mM} \mathrm{NaCl}$ to the shoot induction medium significantly decreased the percentage of shoot induction and number of shoots in both explants as compared with the control (Table 2 and Figures 1(e) and 2(e)). Thus, for further studies $50 \mathrm{mM} \mathrm{NaCl}$ was used. The average number of shoots regenerated per explant decreased on the medium containing $\mathrm{NaCl}$ alone, while there was less decrease when the shoot induction medium was supplemented with both $\mathrm{NaCl}$ and $\mathrm{Si}$ (Table 2 and Figures 1(e)-1(h) and Figures $2(\mathrm{e})-2(\mathrm{~h}))$. The in vitro morphogenetic response of plants also depends on the medium composition. The high concentrations of $\mathrm{Cl}^{-}$and $\mathrm{Na}^{+}$ions led to ion imbalance in the 


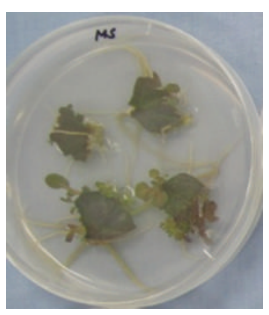

(a)

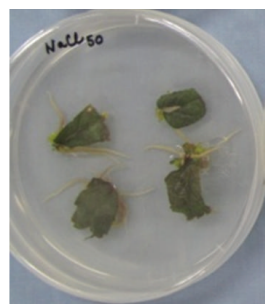

(e)

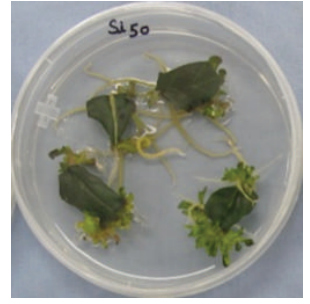

(b)

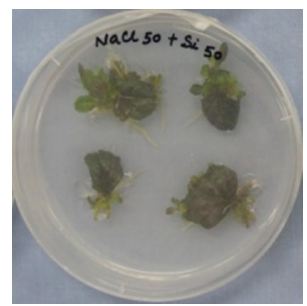

(f)

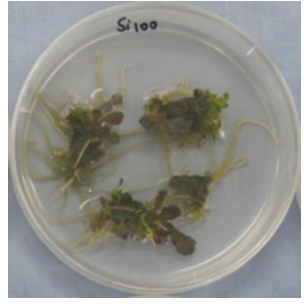

(c)

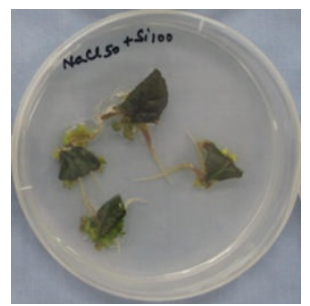

(g)

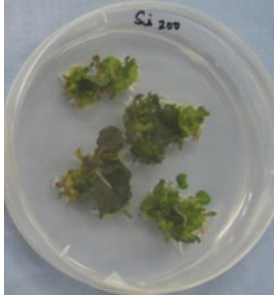

(d)

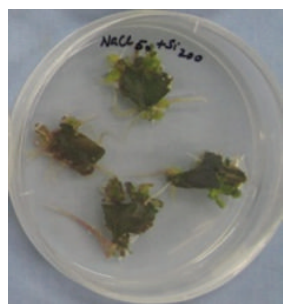

(h)

FIGURE 1: Effect of silicon and $\mathrm{NaCl}$ on adventitious shoot regeneration from leaf explants of $A$. multiflora. (a) MS medium with $12.2 \mu \mathrm{M} 2 \mathrm{iP}$ and $5.7 \mu \mathrm{M}$ IAA (SIM), (b) SIM $+1.8 \mathrm{mM} \mathrm{Si}$, (c) SIM $+3.6 \mathrm{mM} \mathrm{Si}$, (d) SIM $+7.2 \mathrm{mM} \mathrm{Si}$, (e) $\mathrm{SIM}+50 \mathrm{mM} \mathrm{NaCl}$, (f) $\mathrm{SIM}+50 \mathrm{mM} \mathrm{NaCl}+$ $1.8 \mathrm{mM} \mathrm{Si}$, (g) SIM + $50 \mathrm{mM} \mathrm{NaCl}+3.6 \mathrm{mM} \mathrm{Si}$, and (h) SIM $+50 \mathrm{mM} \mathrm{NaCl}+7.2 \mathrm{mM} \mathrm{Si}$.

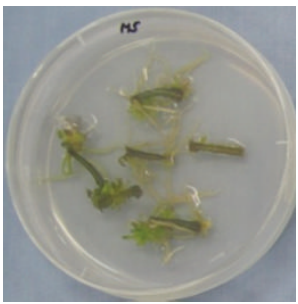

(a)

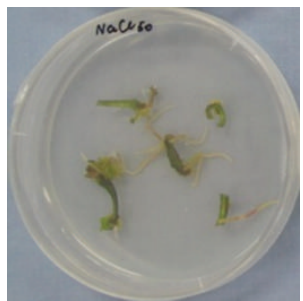

(e)

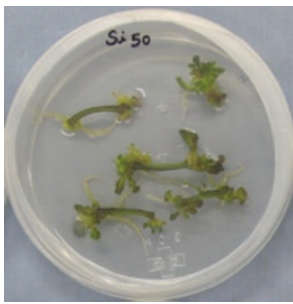

(b)

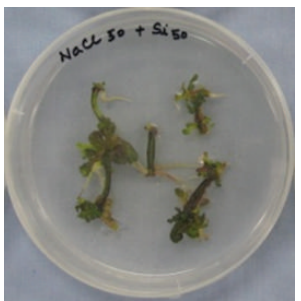

(f)

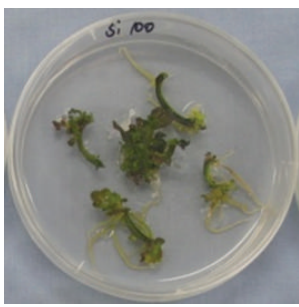

(c)

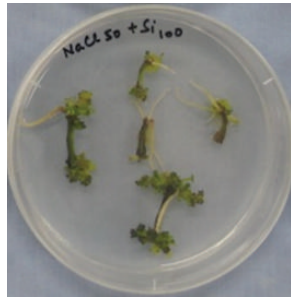

(g)

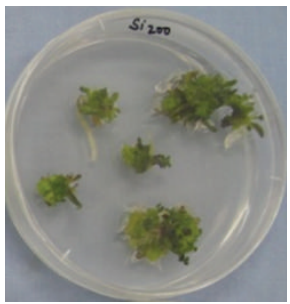

(d)

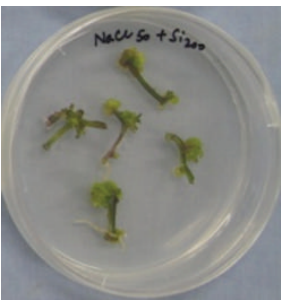

(h)

FIGURE 2: Effect of silicon and $\mathrm{NaCl}$ on adventitious shoot regeneration from leaf explants of $A$. multiflora. (a) MS medium with $12.2 \mu \mathrm{M} 2 \mathrm{iP}$ and $5.7 \mu \mathrm{M}$ IAA (SIM), (b) SIM $+1.8 \mathrm{mM} \mathrm{Si}$, (c) SIM + 3.6 mM Si, (d) SIM + 7.2 mM Si, (e) SIM $+50 \mathrm{mM} \mathrm{NaCl}$, (f) $\mathrm{SIM}+50 \mathrm{mM} \mathrm{NaCl}+$ $1.8 \mathrm{mM} \mathrm{Si},(\mathrm{g}) \mathrm{SIM}+50 \mathrm{mM} \mathrm{NaCl}+3.6 \mathrm{mM} \mathrm{Si}$, and (h) SIM + $50 \mathrm{mM} \mathrm{NaCl}+7.2 \mathrm{mM} \mathrm{Si}$.

culture medium and thereby reduced the number of regenerated shoots per explant. Si plays an important role under conditions of nutrient imbalance [6]. The shoot induction percentage increased linearly with increasing concentration of $\mathrm{Si}$ in the $\mathrm{NaCl}$ containing medium. In both explants, the highest frequency of shoot induction (100\%) was observed on the shoot induction medium containing $50 \mathrm{mM} \mathrm{NaCl}$ and $7.2 \mathrm{mM}$ Si. The highest number of 10.7 shoots per leaf explant and 8.7 shoots per petiole explant was obtained on the shoot induction medium containing $50 \mathrm{mM} \mathrm{NaCl}$ with 7.2 or $3.6 \mathrm{mM} \mathrm{Si}$, respectively.
The regenerated shoots were separated from the explants and cultured on the plant growth regulators free MS medium for further shoot growth and rooting. Addition of Si significantly increased plant height, chlorophyll content, root length, and fresh and dry weights of shoot and root as compared with the control. Inclusion of 1.8 or $3.6 \mathrm{mM}$ Si to the MS medium increased the plant height, but increasing the concentration of Si to $7.2 \mathrm{mM}$ led to shorter plant as compared with the control (Table 3 and Figures 3(a)-3(d)). The average number of leaves per shoot decreased linearly with increasing concentration of Si. The greatest chlorophyll 


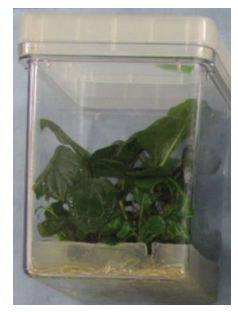

(a)

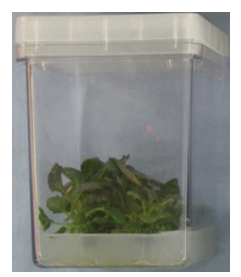

(e)

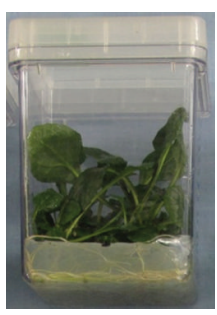

(b)

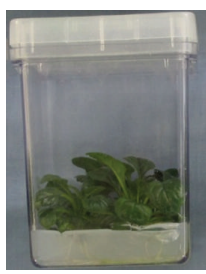

(f)

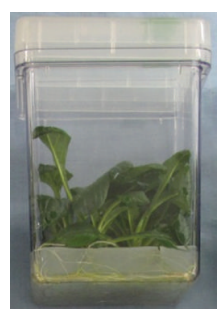

(c)

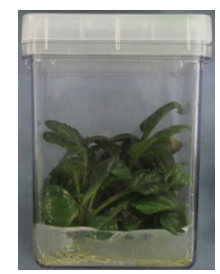

(g)

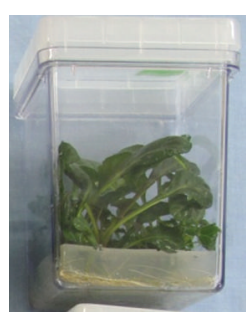

(d)

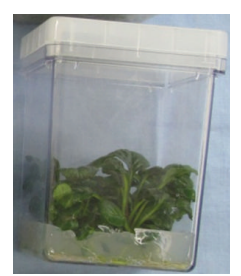

(h)

FIGURE 3: Effect of silicon and $\mathrm{NaCl}$ on shoot growth and rooting of A. multiflora. (a) MS medium, (b) MS + 1.8 mM Si, (c) MS + 3.6 mM Si, (d) $\mathrm{MS}+7.2 \mathrm{mM} \mathrm{Si}$, (e) $\mathrm{MS}+50 \mathrm{mM} \mathrm{NaCl}$, (f) $\mathrm{MS}+50 \mathrm{mM} \mathrm{NaCl}+1.8 \mathrm{mM} \mathrm{Si}$, (g) $\mathrm{MS}+50 \mathrm{mM} \mathrm{NaCl}+3.6 \mathrm{mM} \mathrm{Si}$, and (h) $\mathrm{MS}+50 \mathrm{mM}$ $\mathrm{NaCl}+7.2 \mathrm{mM} \mathrm{Si}$.

TABLE 3: Effect of $\mathrm{Si}$ and $\mathrm{NaCl}$ on growth characteristics of A. multiflora.

\begin{tabular}{|c|c|c|c|c|c|c|c|c|c|}
\hline \multicolumn{2}{|c|}{ Conc. (mM) } & \multirow{2}{*}{ Plant height $(\mathrm{cm})$} & \multirow{2}{*}{ No. of leaves } & \multirow{2}{*}{ Chlorophyll $\left(\mu \mathrm{g} \mathrm{mg}^{-1} \mathrm{fw}\right)$} & \multirow{2}{*}{ Root length $(\mathrm{cm})$} & \multicolumn{2}{|c|}{ Fresh weight (mg) } & \multicolumn{2}{|c|}{ Dry weight (mg) } \\
\hline $\mathrm{Si}$ & $\mathrm{NaCl}$ & & & & & Shoot & Root & Shoot & Root \\
\hline 0 & 0 & $8.1^{\mathrm{b}}$ & $14.2^{\mathrm{a}}$ & $3.04^{\mathrm{c}}$ & $12.6^{\mathrm{C}}$ & $1.28^{f}$ & $0.57^{\mathrm{de}}$ & $0.14^{\mathrm{c}}$ & $0.086^{\mathrm{e}}$ \\
\hline 1.8 & 0 & $8.6^{\mathrm{a}}$ & $13.7^{\mathrm{ab}}$ & $3.59^{\mathrm{b}}$ & $13.0^{\mathrm{bc}}$ & $1.52^{\mathrm{d}}$ & $0.84^{\mathrm{b}}$ & $0.17^{\mathrm{b}}$ & $0.115^{\mathrm{b}}$ \\
\hline 3.6 & 0 & $8.7^{\mathrm{a}}$ & $13.4^{\mathrm{ab}}$ & $3.75^{\mathrm{a}}$ & $13.6^{\mathrm{c}}$ & $1.75^{\mathrm{b}}$ & $0.89^{\mathrm{a}}$ & $0.19^{\mathrm{a}}$ & $0.135^{\mathrm{a}}$ \\
\hline 7.2 & 0 & $7.4^{\mathrm{bc}}$ & $12.1^{\mathrm{b}}$ & $2.83^{\mathrm{d}}$ & $15.4^{\mathrm{a}}$ & $1.70^{\mathrm{c}}$ & $0.71^{\mathrm{c}}$ & $0.18^{\mathrm{ab}}$ & $0.094^{\mathrm{d}}$ \\
\hline 0 & 50 & $4.5^{\mathrm{f}}$ & $8.3^{\mathrm{d}}$ & $0.73^{\mathrm{g}}$ & $7.06^{\mathrm{d}}$ & $1.09^{\mathrm{g}}$ & $0.36^{\mathrm{f}}$ & $0.12^{\mathrm{d}}$ & $0.054^{\mathrm{f}}$ \\
\hline 1.8 & 50 & $5.3^{\mathrm{d}}$ & $12.6^{\mathrm{b}}$ & $2.38^{\mathrm{e}}$ & $14.8^{\mathrm{b}}$ & $1.73^{\mathrm{b}}$ & $0.59^{\mathrm{d}}$ & $0.17^{\mathrm{b}}$ & $0.095^{\mathrm{d}}$ \\
\hline 3.6 & 50 & $6.5^{\mathrm{c}}$ & $12.8^{\mathrm{b}}$ & $3.73^{\mathrm{a}}$ & $15.8^{\mathrm{a}}$ & $1.84^{\mathrm{a}}$ & $0.60^{\mathrm{d}}$ & $0.18^{\mathrm{ab}}$ & $0.102^{\mathrm{c}}$ \\
\hline 7.2 & 50 & $5.2^{\mathrm{d}}$ & $10.5^{\mathrm{c}}$ & $1.66^{\mathrm{f}}$ & $14.7^{\mathrm{b}}$ & $1.36^{\mathrm{e}}$ & $0.53^{\mathrm{e}}$ & $0.17^{\mathrm{b}}$ & $0.091^{\mathrm{de}}$ \\
\hline
\end{tabular}

Means within a column followed by the same letters are not significantly different $(P \leq 0.05)$.

content $\left(3.75 \mu \mathrm{g} \mathrm{mg}^{-1} \mathrm{fw}\right)$ was recorded on the MS medium supplemented with $3.6 \mathrm{mM}$ Si. However, increasing Si concentration above $3.6 \mathrm{mM}$ had a negative effect on chlorophyll content. Root length significantly increased with increasing concentration of $\mathrm{Si}$ in the culture medium. The greatest root length $(15.4 \mathrm{~cm})$ was obtained on the MS medium containing $7.2 \mathrm{mM}$ Si. Addition of Si significantly increased fresh and dry weights of shoot and root as compared with the control. The highest fresh and dry weights of shoot and root were obtained on the MS medium containing 3.6 mM Si. However, addition of $50 \mathrm{mM} \mathrm{NaCl}$ significantly reduced the growth traits of $A$. multiflora as compared with the control (Figure 3(e)). Si has been shown to be effective in alleviating salt stress in various plants. In the present study, Si inclusion promoted growth traits on the medium containing $50 \mathrm{mM} \mathrm{NaCl}$ (Table 3 and Figures $3(\mathrm{~g})$ and $3(\mathrm{~h})$ ). The greatest plant height, number of leaves, chlorophyll content, root length, and fresh and dry weights of shoot and root were obtained on the shoot induction medium containing $50 \mathrm{mM} \mathrm{NaCl}$ and $3.6 \mathrm{mM} \mathrm{Si}$
(Table 3). Similarly, Si treatment enhanced the growth traits of many salt-stressed plants $[6,7]$.

3.3. Estimation of Antioxidant Enzymes. Addition of Si to the culture medium promoted shoot regeneration; however, the mechanism of $\mathrm{Si}$ action is not known. In general, $\mathrm{Si}$ treatment significantly affected the antioxidant enzyme activities in many plants $[6,7]$. Antioxidant enzymes enhanced the growth and morphogenesis in many plants. Thus, we investigated the effect of Si on antioxidant enzyme activities of $A$. multiflora. Addition of Si to the shoot induction medium significantly increased SOD, POD, APX, and CAT activity in regenerated shoot buds as compared with the control (Table 4). Similarly, the activity of antioxidant enzymes increased during organogenesis in Brassica rapa var. turnip [33], Caladium bicolor [34], Crocus sativus [35], Piper nigrum [9], and plum [36]. The activities of SOD and POD increased significantly with increasing concentration of $\mathrm{Si}$ in the shoot induction medium. The activity of CAT was significantly 


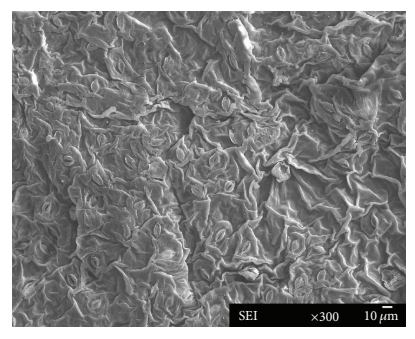

(a)

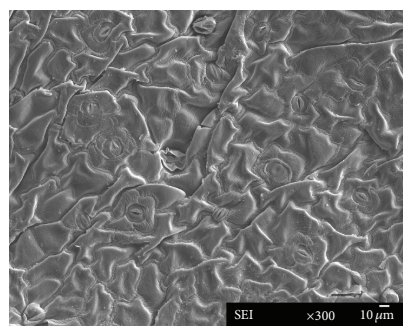

(e)

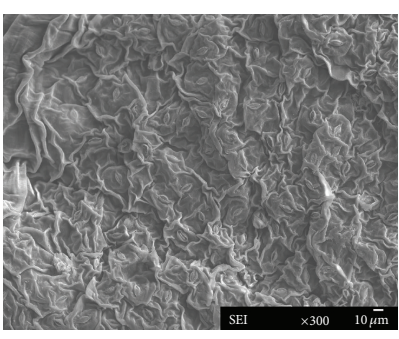

(b)

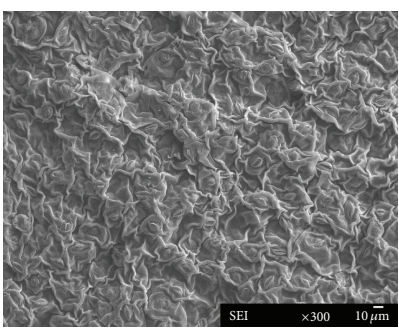

(f)

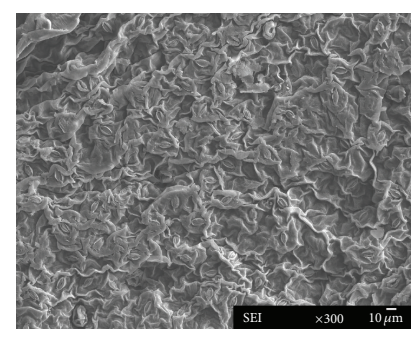

(c)

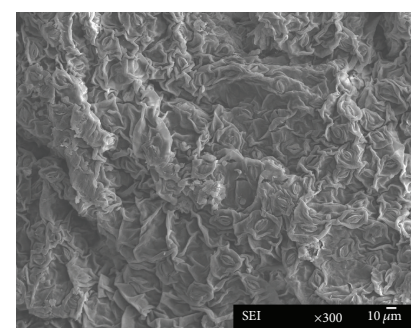

(g)

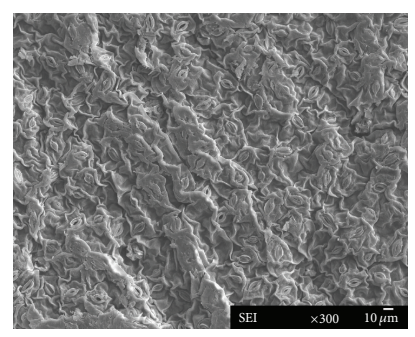

(d)

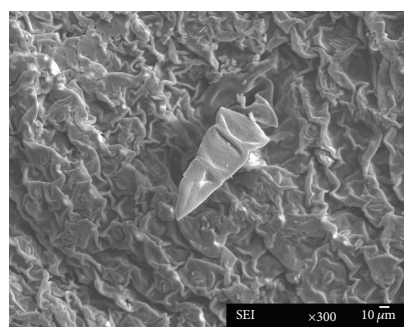

(h)

FIGURE 4: Scanning electron microscopic analysis of A. multiflora leaves treated with silicon and $\mathrm{NaCl}$. (a) MS medium, (b) MS + 1.8 mM Si, (c) $\mathrm{MS}+3.6 \mathrm{mM} \mathrm{Si}$, (d) $\mathrm{MS}+7.2 \mathrm{mM} \mathrm{Si}$, (e) $\mathrm{MS}+50 \mathrm{mM} \mathrm{NaCl}$, (f) $\mathrm{MS}+50 \mathrm{mM} \mathrm{NaCl}+1.8 \mathrm{mM} \mathrm{Si}$, (g) MS + $50 \mathrm{mM} \mathrm{NaCl}+3.6 \mathrm{mM} \mathrm{Si}$, and (h) $\mathrm{MS}+50 \mathrm{mM} \mathrm{NaCl}+7.2 \mathrm{mMSi}$.

TABLE 4: Effect of Si on antioxidant enzyme activities $\left(\mathrm{U} \mathrm{mg}^{-1}\right.$ protein) in regenerated shoot buds of A. multiflora.

\begin{tabular}{lcccc}
\hline Si $(\mathrm{mM})$ & SOD & POD & APX & CAT \\
\hline 0 & $0.093^{\mathrm{d}}$ & $1.28^{\mathrm{c}}$ & $17.14^{\mathrm{c}}$ & $1.62^{\mathrm{c}}$ \\
1.8 & $0.113^{\mathrm{c}}$ & $1.38^{\mathrm{c}}$ & $17.43^{\mathrm{c}}$ & $1.87^{\mathrm{bc}}$ \\
3.6 & $0.126^{\mathrm{b}}$ & $2.66^{\mathrm{b}}$ & $26.08^{\mathrm{a}}$ & $2.56^{\mathrm{a}}$ \\
7.2 & $0.133^{\mathrm{a}}$ & $3.33^{\mathrm{a}}$ & $19.41^{\mathrm{b}}$ & $1.99^{\mathrm{b}}$ \\
\hline
\end{tabular}

Data represent mean of six independent measurements.

Means within a column followed by the same letters are not significantly different $(P \leq 0.05)$.

higher on the shoot induction medium containing $3.6 \mathrm{mM}$ $\mathrm{Si}$. Inclusion of $1.8 \mathrm{mM} \mathrm{Si}$ did not change the APX activity as compared with the control. However, the activity of APX was significantly increased by 3.8 or $7.8 \mathrm{mM}$ Si treatment (Table 4). Thus, apparently Si promoted shoot regeneration of $A$. multiflora by altering activity of antioxidant enzymes.

We also estimated the antioxidant enzymes activities in leaves and roots of plantlets grown in the medium containing $\mathrm{Si}$ and $\mathrm{NaCl}$ alone or in combination of $\mathrm{Si}$ and $\mathrm{NaCl}$. Inclusion of $\mathrm{Si}$ to the MS medium increased SOD in both leaves and roots as compared with the control. In contrast, addition of $\mathrm{NaCl}$ to the MS medium significantly decreased SOD activity in both leaves and roots as compared with the control. However, inclusion of $\mathrm{Si}$ to the $\mathrm{NaCl}$ containing medium significantly increased the SOD activity in both organs. Similarly, Si treatment increased leaf and root SOD activity in barley under $\mathrm{NaCl}$ stress in vivo [37]. The activity of SOD was significantly higher in both organs when the MS medium was supplemented with $3.6 \mathrm{mM} \mathrm{Si}$. Si treatment significantly decreased POD activity in leaves, whereas inclusion of Si to the MS medium significantly increased POD activity in roots
(Table 5). Addition of $\mathrm{NaCl}$ to the MS medium significantly increased POD activity in leaves, whereas it did not affect POD activity in roots as compared with the control. In leaves, the activity of POD was decreased on the culture medium containing both $\mathrm{NaCl}$ and Si. When the $\mathrm{NaCl}$ containing medium was supplemented with 3.6 or $7.2 \mathrm{mM}$ Si the activity of POD in roots was significantly increased or decreased, respectively. In both leaves and roots, the activity of APX increased linearly with increasing concentrations of $\mathrm{Si}$ in the MS medium. Addition of $\mathrm{NaCl}$ to the MS medium significantly increased the activity of APX in both leaves and roots as compared with the control and other treatments. Inclusion of $\mathrm{Si}$ to the $\mathrm{NaCl}$ containing medium significantly decreased the APX activity in both organs. Similarly, the activity of CAT was significantly higher when the MS medium was supplemented with $50 \mathrm{mM} \mathrm{NaCl}$. However, addition of $\mathrm{Si}$ decreased the CAT activity in both organs as compared with the $50 \mathrm{mM} \mathrm{NaCl}$ treatment (Table 5). Similar results were also reported in lettuce [38] and tomato [39]. In contrast, addition of Si increased the activities of CAT and APX in salt-stressed barley [40] and cucumber [41].

3.4. SEM and WDXA. The SEM analysis showed that there is no distinct difference in the structure of stomata between the control and Si-treated plants (Figures 4(a)-4(d)). Similar result was observed in maize [42] on in vivo Si treatment. In contrast, addition of $\mathrm{Si}$ to the MS medium altered the stomata structure in begonia and pansy [43]. The functions, structure, and number of stomata were adversely affected by salinity. In the present study, $\mathrm{NaCl}$ treatment significantly affected the structure and number of stomata as compared to the control (Figure 4(e)). The leaf surface and stomata were normal when the $\mathrm{NaCl}$ containing medium was 
TABLE 5: Effect of $\mathrm{Si}$ and $\mathrm{NaCl}$ on antioxidant enzyme activities of $A$. multiflora.

\begin{tabular}{|c|c|c|c|c|c|c|c|c|c|}
\hline \multicolumn{2}{|c|}{ Conc. (mM) } & \multicolumn{4}{|c|}{ Leaf ( $\mathrm{U} \mathrm{mg}^{-1}$ protein) } & \multicolumn{4}{|c|}{ Root (U mg ${ }^{-1}$ protein) } \\
\hline $\mathrm{Si}$ & $\mathrm{NaCl}$ & SOD & POD & APX & CAT & SOD & POD & APX & CAT \\
\hline 0 & 0 & $0.030^{\mathrm{c}}$ & $1.99^{\mathrm{a}}$ & $3.33^{\mathrm{e}}$ & $0.95^{f}$ & $0.041^{\mathrm{d}}$ & $2.03^{b c}$ & $5.54^{\mathrm{e}}$ & $1.91^{\mathrm{c}}$ \\
\hline 1.8 & 0 & $0.032^{\mathrm{bc}}$ & $1.42^{\mathrm{b}}$ & $4.01^{\mathrm{d}}$ & $0.71^{\mathrm{g}}$ & $0.047^{\mathrm{c}}$ & $2.44^{\mathrm{b}}$ & $5.41^{\mathrm{e}}$ & $2.15^{\mathrm{b}}$ \\
\hline 3.6 & 0 & $0.039^{\mathrm{a}}$ & $1.10^{\mathrm{c}}$ & $4.24^{\mathrm{cd}}$ & $1.29^{\mathrm{e}}$ & $0.050^{\mathrm{b}}$ & $2.78^{\mathrm{a}}$ & $5.92^{\mathrm{d}}$ & $2.20^{\mathrm{b}}$ \\
\hline 7.2 & 0 & $0.035^{\mathrm{b}}$ & $0.72^{\mathrm{d}}$ & $4.84^{\mathrm{c}}$ & $1.41^{\mathrm{d}}$ & $0.045^{\mathrm{c}}$ & $2.86^{\mathrm{a}}$ & $6.11^{\mathrm{cd}}$ & $2.39^{\mathrm{b}}$ \\
\hline 0 & 50 & $0.013^{\mathrm{e}}$ & $2.78^{\mathrm{a}}$ & $6.63^{\mathrm{a}}$ & $2.93^{\mathrm{a}}$ & $0.028^{\mathrm{e}}$ & $2.13^{\mathrm{bc}}$ & $8.90^{\mathrm{a}}$ & $3.76^{\mathrm{a}}$ \\
\hline 1.8 & 50 & $0.026^{\mathrm{d}}$ & $2.57^{\mathrm{b}}$ & $6.42^{\mathrm{a}}$ & $2.76^{\mathrm{b}}$ & $0.044^{\text {cd }}$ & $2.41^{\mathrm{b}}$ & $7.33^{\mathrm{b}}$ & $3.31^{\mathrm{b}}$ \\
\hline 3.6 & 50 & $0.033^{\mathrm{bc}}$ & $2.15^{\mathrm{c}}$ & $5.82^{\mathrm{b}}$ & $1.69^{c}$ & $0.049^{\mathrm{b}}$ & $2.70^{\mathrm{a}}$ & $6.62^{\mathrm{c}}$ & $3.09^{\mathrm{bc}}$ \\
\hline 7.2 & 50 & $0.028^{\mathrm{cd}}$ & $1.75^{\mathrm{de}}$ & $5.90^{\mathrm{b}}$ & $1.44^{\mathrm{d}}$ & $0.058^{\mathrm{a}}$ & $1.82^{\mathrm{C}}$ & $4.44^{\mathrm{f}}$ & $2.83^{\mathrm{d}}$ \\
\hline
\end{tabular}

Data represent mean of six independent measurements.

Means within a column followed by the same letters are not significantly different $(P \leq 0.05)$.

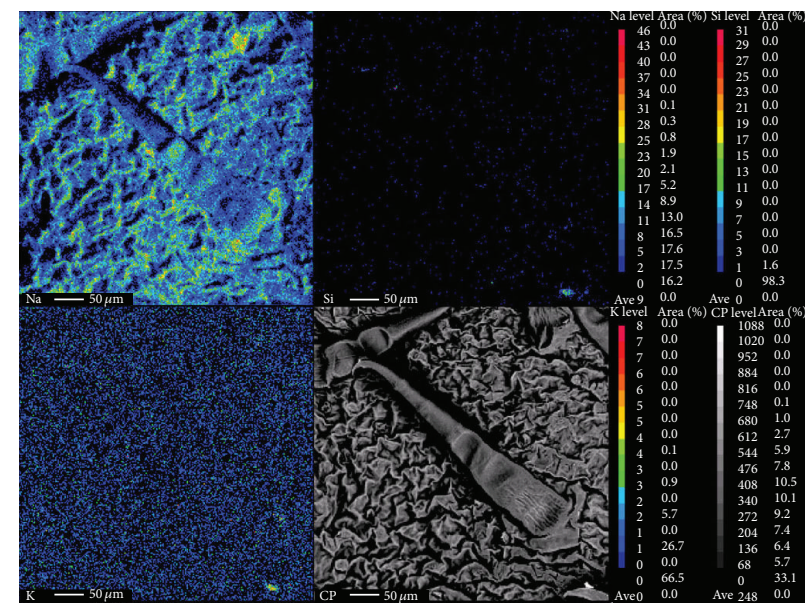

(a)

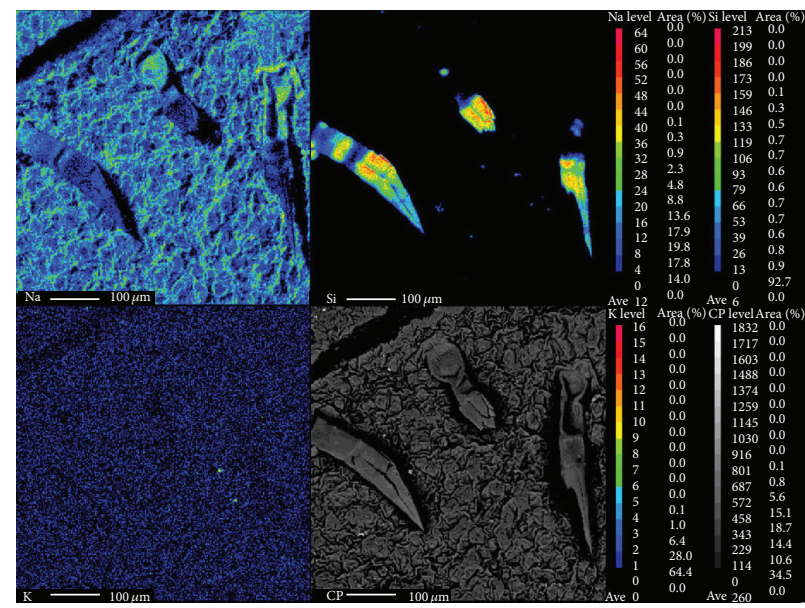

(b)

FIGURE 5: Wavelength dispersive X-ray analysis of Si-treated and nontreated leaves of A. multiflora. (a) MS medium and (b) MS + Si.

supplemented with 1.8-7.2 $\mathrm{mM} \mathrm{Si}$, but changes in the leaf surface were observed among the treatments (Figures $4(\mathrm{f})-$ $4(\mathrm{~h}))$. It has been reported that in several plant species $\mathrm{Si}$ mostly accumulates in leaves than other organs. In leaves, $\mathrm{Si}$ is accumulated mainly in epidermal cells, stomata, and trichomes $[44,45]$. In the present study, WDXA confirmed the high Si deposition in trichomes of plants grown in the $\mathrm{Si}$ containing medium but not in plants grown in the medium without Si (Figures 5(a) and 5(b)). We also examined Si, $\mathrm{K}$, and $\mathrm{Na}$ deposition in stomata of plants grown in the medium containing $\mathrm{Si}$ and $\mathrm{NaCl}$ alone or in combination. The Si deposition was observed in leaf surface of plants grown in the $\mathrm{Si}$ or $\mathrm{Si}+\mathrm{NaCl}$ containing medium but not in the $\mathrm{Si}$ deprived or $\mathrm{NaCl}$ containing medium. The 3.6 mM Si treatment significantly increased the $\mathrm{K}$ deposition as compared with the control and other treatments. The deposition of $\mathrm{Na}$ was increased when the MS medium was supplemented with $50 \mathrm{mM} \mathrm{NaCl}$. However, addition of $\mathrm{Si}$ to the $\mathrm{NaCl}$ containing medium significantly reduced the deposition of $\mathrm{Na}$ in a dose-dependent manner (Figures 6(A)$6(\mathrm{H})$ ). Similarly, concentration of $\mathrm{Na}$ in shoots of barley
[46], Phaseolus vulgaris [47], and rice [48] was decreased by inclusion of $\mathrm{Si}$.

In conclusion, addition of $\mathrm{Si}$ to the culture medium promoted shoot regeneration of $A$. multiflora by altering activity of antioxidant enzymes. The inclusion of $\mathrm{NaCl}$ significantly decreased shoot regeneration and growth of $A$. multiflora. Addition of $\mathrm{Si}$ to the $\mathrm{NaCl}$ containing medium enhanced shoot regeneration and growth of $A$. multiflora by altering activity of antioxidant enzymes, maintenance of ultra structure of stomata, and limiting $\mathrm{NaCl}$ deposition in leaves. The present study can also be used for commercial extraction of active ingredients for pest management purposes.

\section{Conflict of Interests}

The authors declare that there is no conflict of interests regarding the publication of this paper.

\section{Acknowledgment}

This research was supported by Technology Development Program for Agriculture and Forestry, Ministry for Food, 


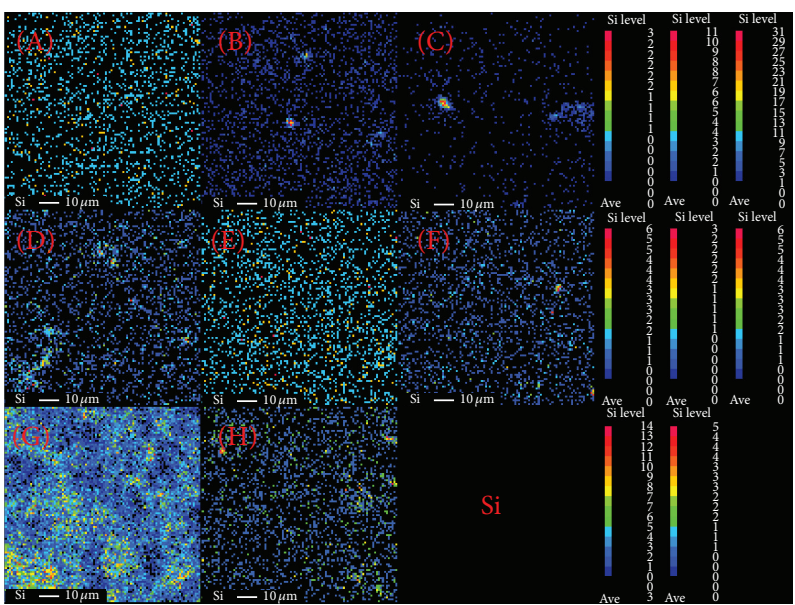

(a)

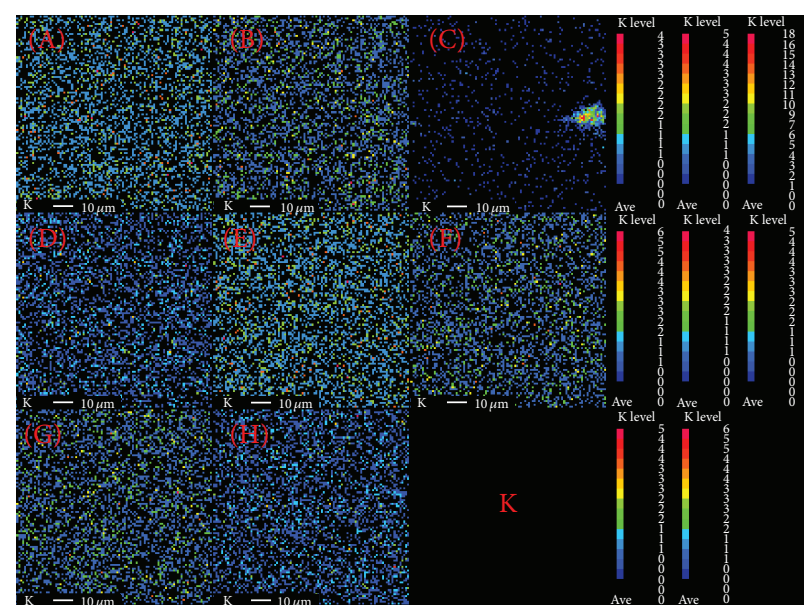

(b)

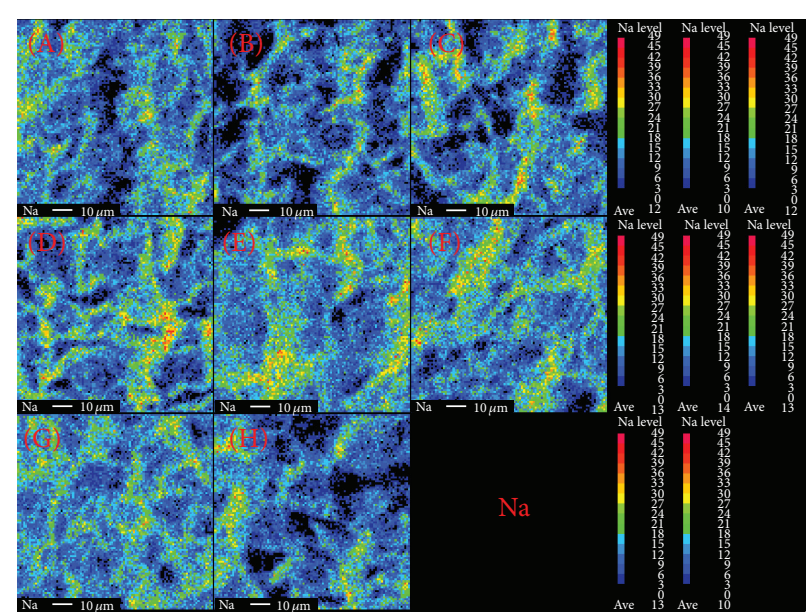

(c)

FIGURE 6: Wavelength dispersive X-ray analysis of $\mathrm{Si}, \mathrm{K}$, and $\mathrm{Na}$ in leaves of A. multiflora treated with silicon and $\mathrm{NaCl}$. (A) MS medium, (B) $\mathrm{MS}+1.8 \mathrm{mM} \mathrm{Si},(\mathrm{C}) \mathrm{MS}+3.6 \mathrm{mM} \mathrm{Si}$, (D) MS + 7.2 mM Si, (E) MS + $50 \mathrm{mM} \mathrm{NaCl},(\mathrm{F}) \mathrm{MS}+50 \mathrm{mM} \mathrm{NaCl}+1.8 \mathrm{mM} \mathrm{Si},(\mathrm{G}) \mathrm{MS}+50 \mathrm{mM}$ $\mathrm{NaCl}+3.6 \mathrm{mM} \mathrm{Si}$, and $(\mathrm{H}) \mathrm{MS}+50 \mathrm{mM} \mathrm{NaCl}+7.2 \mathrm{mM} \mathrm{Si}$.

Agriculture, Forestry and Fisheries, Republic of Korea (Project no. 108102-5).

\section{References}

[1] E. Epstein, "Silicon," Annual Review of Plant Biology, vol. 50, pp. 641-664, 1999.

[2] J. F. Ma and E. Takahashi, "Functions of silicon in plant growth," in Soil, Fertilizer, and Plant Silicon Research in Japan, J. F. Ma and E. Takahashi, Eds., pp. 107-180, Elsevier, Amsterdam, The Netherlands, 2002.

[3] S. Kamenidou, T. J. Cavins, and S. Marek, "Silicon supplements affect floricultural quality traits and elemental nutrient concentrations of greenhouse produced gerbera," Scientia Horticulturae, vol. 123, no. 3, pp. 390-394, 2010.

[4] N. S. Mattson and W. R. Leatherwood, "Potassium silicate drenches increase leaf silicon content and affect morphological traits of several floriculture crops grown in a peat-based substrate," HortScience, vol. 45, no. 1, pp. 43-47, 2010.
[5] I. Sivanesan, M. S. Son, J. P. Lee, and B. R. Jeong, "Effects of silicon on growth of Tagetes patula 1. "Boy orange" and "Yellow Boy" seedlings cultured in an environment controlled chamber," Propagation of Ornamental Plants, vol. 10, no. 3, pp. 136-140, 2010.

[6] J. F. Ma, "Role of silicon in enhancing the resistance of plants to biotic and abiotic stresses," Soil Science and Plant Nutrition, vol. 50, no. 1, pp. 11-18, 2004.

[7] Y. Liang, W. Sun, Y. Zhu, and P. Christie, "Mechanisms of silicon-mediated alleviation of abiotic stresses in higher plants: a review," Environmental Pollution, vol. 147, no. 2, pp. 422-428, 2007.

[8] I. Sivanesan and B. R. Jeong, "Micropropagation of Rhododendron keiskei var. hypoglaucum Suto \& Suzuki and assessment of clonal fidelity of plantlets by RAPD," Propagation of Ornamental Plants, vol. 13, pp. 123-129, 2013.

[9] N. Ahmad, B. H. Addasi, I. Rahman, and H. Fazal, "Piper nigrum: micropropagation, antioxidative enzyme activities, and chromatographic fingerprint analysis for quality control," Applied Biochemistry and Biotechnology, vol. 169, no. 7, pp. 2004-2015, 2013. 
[10] M. W. Bairu and M. E. Kane, "Physiological and developmental problems encountered by in vitro cultured plants," Plant Growth Regulation, vol. 63, no. 2, pp. 101-103, 2011.

[11] I. Sivanesan, J. Y. Song, S. J. Hwang, and B. R. Jeong, "Micropropagation of Cotoneaster wilsonii Nakai-a rare endemic ornamental plant," Plant Cell, Tissue and Organ Culture, vol. 105, no. 1, pp. 55-63, 2011.

[12] M. Ziv, "Silicon effects on growth acclimatization and stress tolerance of bioreactor cultured Ornithogalum dubium plants," Acta Horticulturae, vol. 865, pp. 29-36, 2010.

[13] M. M. Islam, M. Ahmed, and D. Mahaldar, "In Vitro callus induction and plant regeneration in seed explants of rice (Oryza sativa L.)," Research Journal of Agriculture and Biological Sciences, vol. 1, pp. 72-75, 2005.

[14] C. Máthé, Á. Mosolygó, G. Surányi et al., “Genotype and explant-type dependent morphogenesis and silicon response of common reed (Phragmites australis) tissue cultures," Aquatic Botany, vol. 97, no. 1, pp. 57-63, 2012.

[15] L. A. Valdez-Aguilar, C. M. Grieve, and J. Poss, "Salinity and alkaline $\mathrm{pH}$ in irrigation water affect marigold plants: I. Growth and shoot dry weight partitioning," HortScience, vol. 44, no. 6, pp. 1719-1725, 2009.

[16] C. Cassaniti, D. Romano, M. E. C. M. Hop, and T. J. Flowers, "Growing floricultural crops with brackish water," Environmental and Experimental Botany, vol. 92, pp. 165-175, 2013.

[17] K. Vijayan, S. P. Chakraborti, and P. D. Ghosh, "In Vitro screening of mulberry (Morus spp.) for salinity tolerance," Plant Cell Reports, vol. 22, no. 5, pp. 350-357, 2003.

[18] Z. H. Israili and B. Lyoussi, "Ethnopharmacology of the plants of genus Ajuga," Pakistan Journal of Pharmaceutical Sciences, vol. 22, no. 4, pp. 425-462, 2009.

[19] C. De-fu, S. Ming-xue, and X. Wen-fu, "Pesticidal character of phytoecdysteroids from Ajuga multiflora Bunge (Labiatae) on larvae of Cryptorrhynchus lapathi L., (Coleoptera: Curculionidae)," Journal of Forestry Research, vol. 13, no. 3, pp. 177-182, 2002.

[20] N. Tanaka and T. Matsumoto, "Regenerants from Ajuga hairy roots with high productivity of 20-hydroxyecdysone," Plant Cell Reports, vol. 13, no. 2, pp. 87-90, 1993.

[21] N. Uozumi, Y. Ohtake, Y. Nakashimada, Y. Morikawa, N. Tanaka, and T. Kobayashi, "Efficient regeneration from GUStransformed Ajuga hairy root," Journal of Fermentation and Bioengineering, vol. 81, no. 5, pp. 374-378, 1996.

[22] I. Sivanesan, C. H. Ko, J. P. Lee, and B. R. Jeong, "Influence of cytokinins on adventitious shoot regeneration from leaf and petiole explants of Ajuga multiflora bunge," Propagation of Ornamental Plants, vol. 11, no. 3, pp. 156-158, 2011.

[23] T. Murashige and F. Skoog, "A revised medium for rapid growth and bioassays with tobacco tissue cultures," Physiologia Plantarum, vol. 15, no. 3, pp. 473-497, 1962.

[24] O. H. Lowry, N. J. Rosebrough, A. L. Farr, and R. L. Randall, "Protein measurement with the Folin phenol reagent," The Journal of Biological Chemistry, vol. 193, no. 1, pp. 265-275, 1951.

[25] C. Beauchamp and I. Fridovich, "Superoxide dismutase: improved assays and an assay applicable to acrylamide gels," Analytical Biochemistry, vol. 44, no. 1, pp. 276-287, 1971.

[26] S. Sadasivam and A. Manickam, "Enzymes," in Biochemical Methods, S. Sadasivam and A. Manickam, Eds., pp. 121-124, New Age International, New Delhi, India, 1996.
[27] G. X. Chen and K. Asada, "Ascorbate peroxidase in tea leaves: occurrence of two isozymes and the differences in their enzymatic and molecular properties," Plant and Cell Physiology, vol. 30, no. 7, pp. 987-998, 1989.

[28] H. Aebi, "Catalase in vitro," Methods in Enzymology C, vol. 105, pp. 121-126, 1984.

[29] S. J. Hwang, M. Hamayun, H. Y. Kim et al., "Effect of nitrogen and silicon nutrition on bioactive gibberellins and growth of rice under field conditions," Journal of Crop Science and Biotechnology, vol. 10, no. 4, pp. 281-286, 2007.

[30] S. Isogai, K. Touno, and K. Shimomura, "Gibberellic acid improved shoot multiplication in Cephaelis ipecacuanha," In Vitro Cellular and Developmental Biology, vol. 44, no. 3, pp. 216-220, 2008.

[31] N. Kaushal, M. Modgil, M. Thakur, and D. R. Sharma, "In Vitro clonal multiplication of an apple rootstock by culture of shoot apices and axillary buds," Indian Journal of Experimental Biology, vol. 43, no. 6, pp. 561-565, 2005.

[32] O. Pérez-Tornero, C. I. Tallón, and I. Porras, "An efficient protocol for micropropagation of lemon (Citrus limon) from mature nodal segments," Plant Cell, Tissue and Organ Culture, vol. 100, no. 3, pp. 263-271, 2010.

[33] B. H. Abbasi, M. Khan, B. Guo, S. A. Bokhari, and M. A. Khan, "Efficient regeneration and antioxidative enzyme activities in Brassica rapa var. turnip," Plant Cell, Tissue and Organ Culture, vol. 105, no. 3, pp. 337-344, 2011.

[34] T. Isah and A. Mujib, "Studies on antioxidant enzymes activity during in vitro morphogenesis of Caladium bicolor Linn," International Journal of Modern Cellular and Molecular Biology, vol. 1, no. 1, pp. 1-9, 2011.

[35] E. Vatankhah, V. Niknam, and H. Ebrahimzadeh, "Activity of antioxidant enzyme during in vitro organogenesis in Crocus sativus," Biologia Plantarum, vol. 54, no. 3, pp. 509-514, 2010.

[36] M. Faize, L. Faize, C. Petri et al., "Cu/Zn superoxide dismutase and ascorbate peroxidase enhance in vitro shoot multiplication in transgenic plum," Journal of Plant Physiology, vol. 170, no. 7, pp. 625-632, 2013.

[37] Y. C. Liang, "Effect of silicon on leaf ultrastructure, chlorophyll content and photosynthetic activity of barley under salt stress," Pedosphere, vol. 8, no. 4, pp. 289-296, 1998.

[38] C. J. Milne, C. P. Laubscher, P. A. Ndakidemi, J. L. Marnewick, and F. Rautenbach, "Salinity induced changes in oxidative stress and antioxidant status as affected by applications of silicon in lettuce (Lactuca sativa)," International Journal of Agriculture \& Biology, vol. 14, no. 5, pp. 763-768, 2012.

[39] K. Al-aghabary, Z. Zhu, and Q. Shi, "Influence of silicon supply on chlorophyll content, chlorophyll fluorescence, and antioxidative enzyme activities in tomato plants under salt stress," Journal of Plant Nutrition, vol. 27, no. 12, pp. 2101-2115, 2004.

[40] Y. Liang, Q. Chen, Q. Liu, W. Zhang, and R. Ding, "Exogenous silicon $(\mathrm{Si})$ increases antioxidant enzyme activity and reduces lipid peroxidation in roots of salt-stressed barley (Hordeum vulgare L.)," Journal of Plant Physiology, vol. 160, no. 10, pp. 11571164, 2003.

[41] S. Lechno, E. Zamski, and E. Tel-Or, "Salt stress-induced responses in cucumber plants," Journal of Plant Physiology, vol. 150, no. 1-2, pp. 206-211, 1997.

[42] X. Gao, C. Zou, L. Wang, and F. Zhang, "Silicon decreases transpiration rate and conductance from stomata of maize plants," Journal of Plant Nutrition, vol. 29, no. 9, pp. 1637-1647, 2006. 
[43] M. Y. Lim, E. J. Lee, S. Jana, I. Sivanesan, and B. R. Jeong, "Effect of potassium silicate on growth and leaf epidermal characteristics of begonia and pansy grown in vitro," Korean Journal of Horticultural Science and Technology, vol. 30, pp. 579585, 2012.

[44] A. Lux, M. Luxová, J. Abe, S. Morita, and S. Inanaga, "Silicification of bamboo (Phyllostachys heterocycla Mitf.) root and leaf," Plant and Soil, vol. 255, no. 1, pp. 85-91, 2003.

[45] C. K. Morikawa and M. Saigusa, "Mineral composition and accumulation of silicon in tissues of blueberry (Vaccinum corymbosus cv. Bluecrop) cuttings," Plant and Soil, vol. 258, no. 1-2, pp. 1-8, 2004.

[46] Y. C. Liang, "Effects of silicon on enzyme activity and sodium, potassium and calcium concentration in barley under salt stress," Plant and Soil, vol. 209, no. 2, pp. 217-224, 1999.

[47] A. R. Yeo, S. A. Flowers, G. Rao, K. Welfare, N. Senanayake, and T. J. Flowers, "Silicon reduces sodium uptake in rice (Oryza sativa L.) in saline conditions and this is accounted for by a reduction in the transpirational bypass flow," Plant, Cell and Environment, vol. 22, no. 5, pp. 559-565, 1999.

[48] P. Zuccarini, "Effects of silicon on photosynthesis, water relations and nutrient uptake of Phaseolus vulgaris under $\mathrm{NaCl}$ stress," Biologia Plantarum, vol. 52, no. 1, pp. 157-160, 2008. 

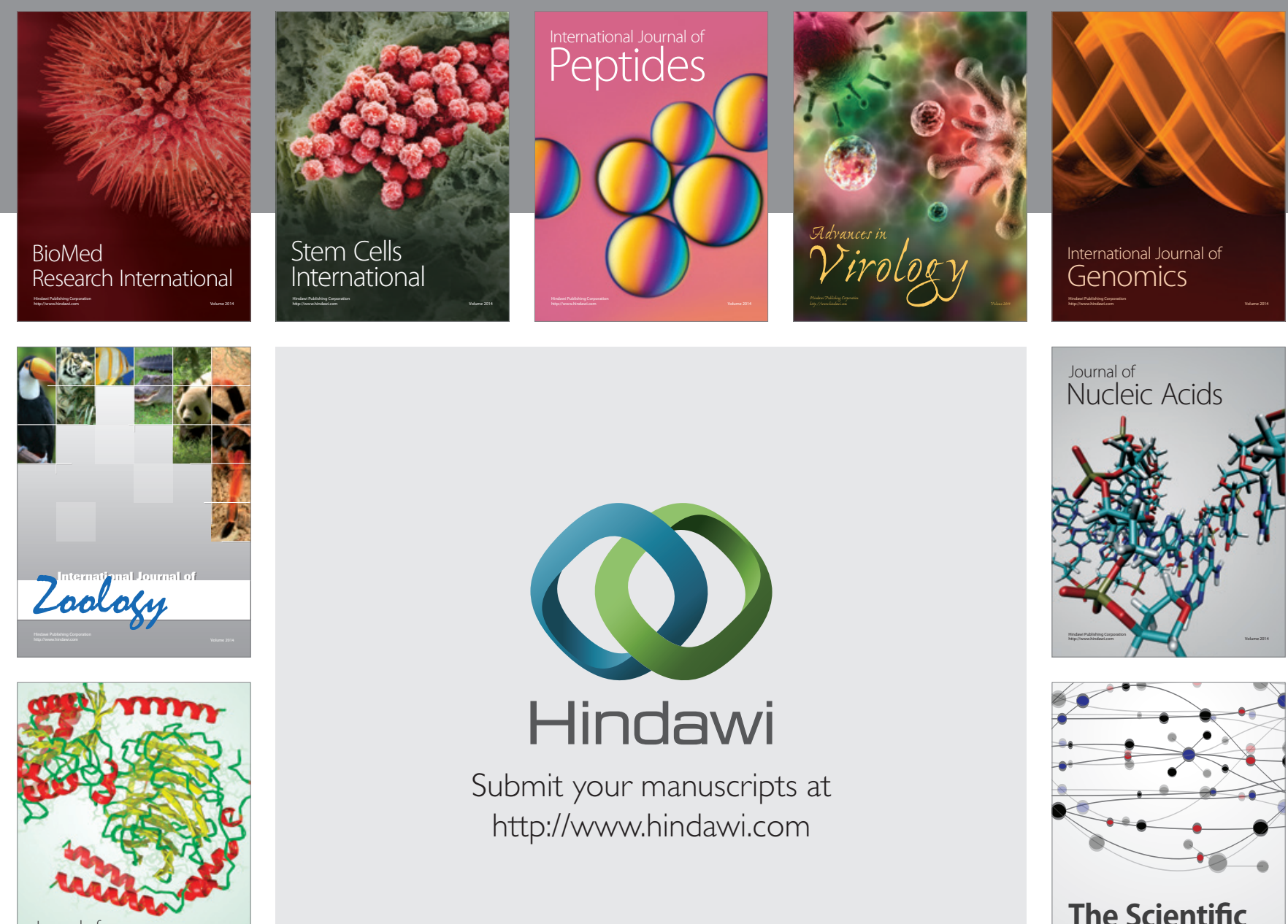

Submit your manuscripts at

http://www.hindawi.com

Journal of
Signal Transduction
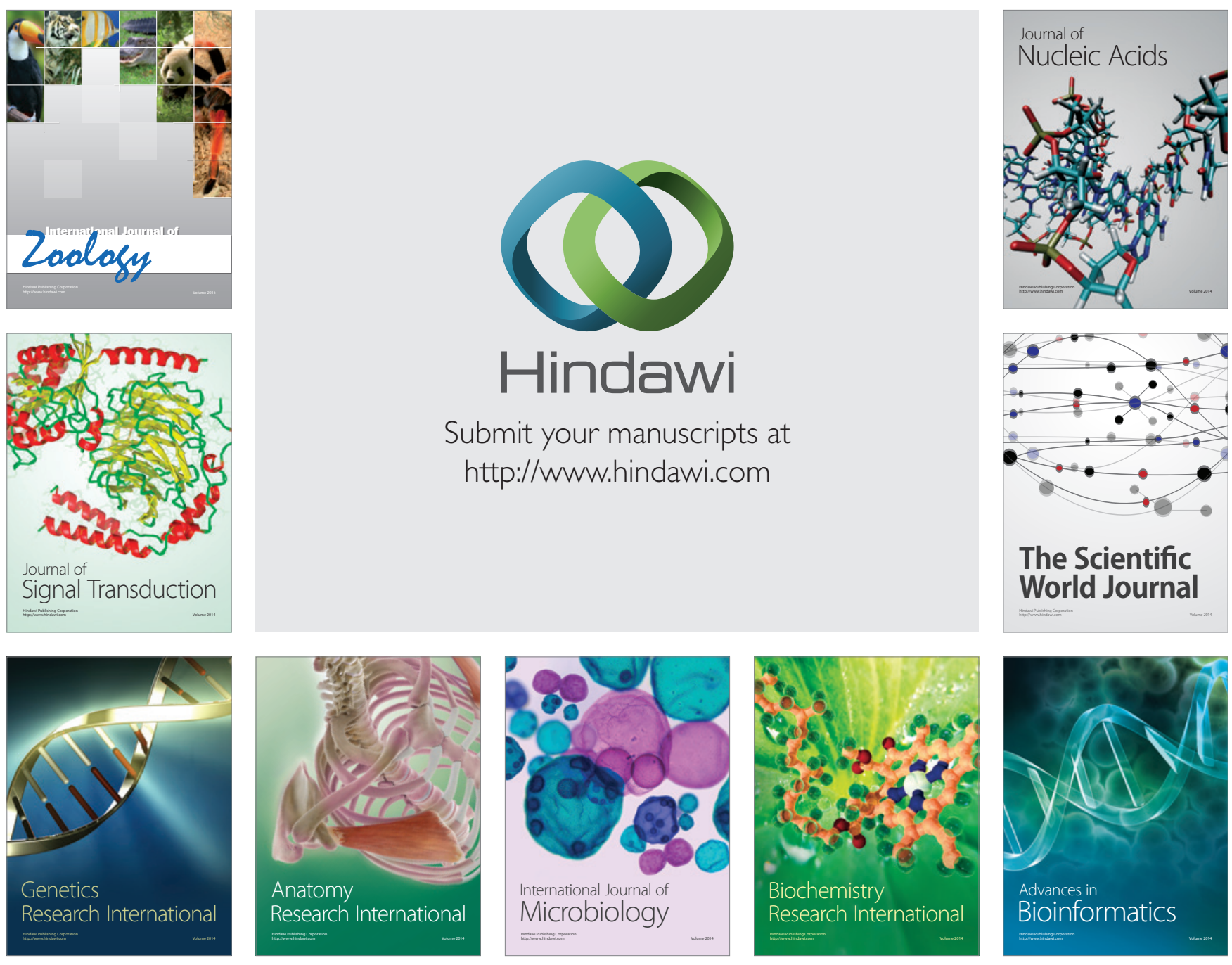

The Scientific World Journal
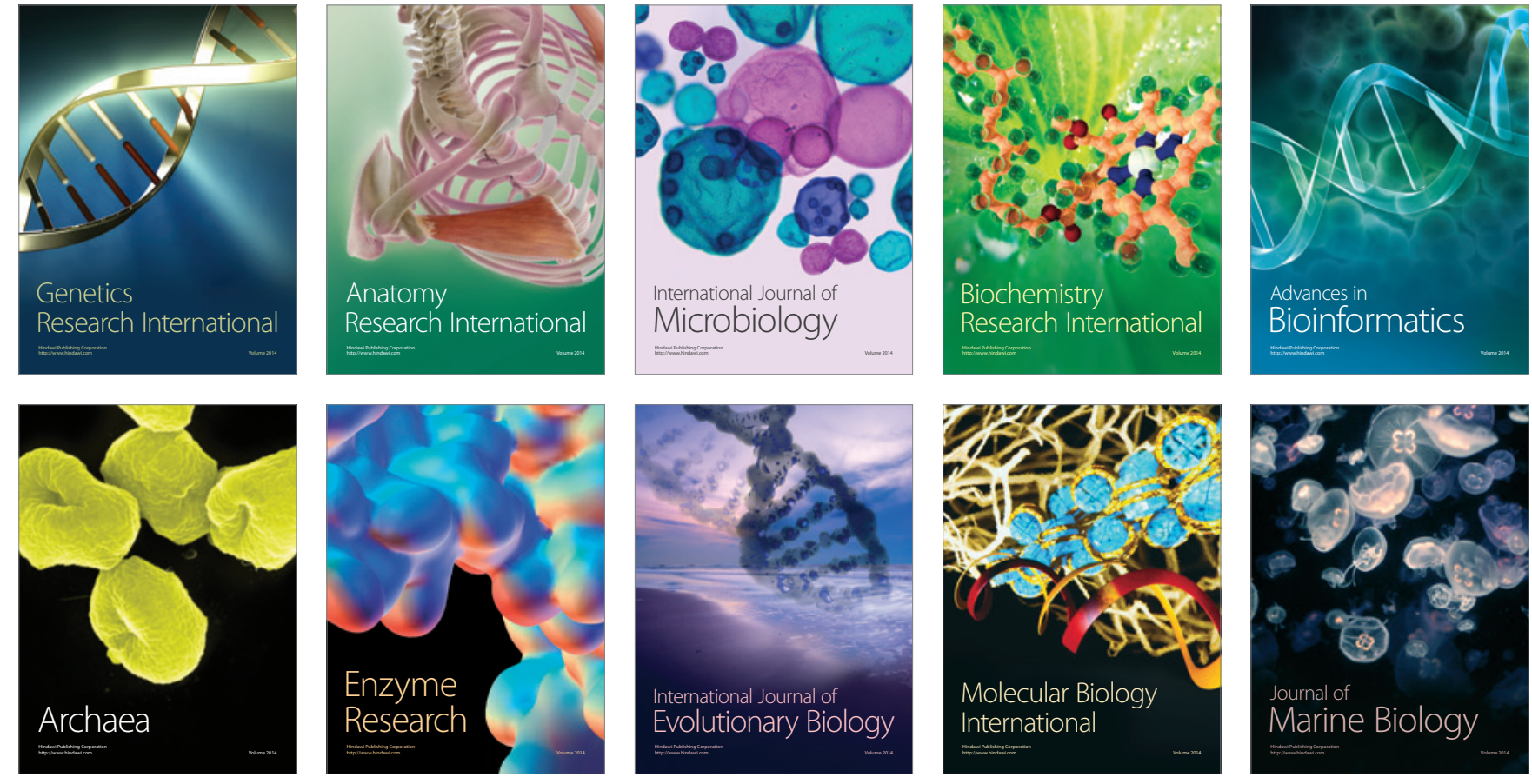